\title{
Evaluation of the Anticonvulsant Activity of the Aqueous Extract of Crinum Scillifolium Bulbs (Amaryllidaceae) In Experimental Animals
}

\author{
Koua Kadio Brou Donald ${ }^{1}$, N'Tamon Amon Diane Marina ${ }^{2}$, \\ Okpekon Aboua Timothée ${ }^{2}$, Kouakou Sylvain Landry ${ }^{3}$, Yapi Houphouet Felix ${ }^{1}$. \\ ${ }^{1}$ Laboratory of Biochemical Pharmacodynamics, UFR Biosciences, Felix Houphouët Boigny University, P.O. \\ Box 582, Abidjan, 22, Côte d'Ivoire. \\ ${ }^{2}$ Laboratory of Organic Chemistry and Natural Substances, UFR Sciences of Structures of Matter and \\ Technology, Felix Houphouët Boigny University, P.O. Box 582, Abidjan, 22, Côte d'Ivoire. \\ ${ }^{3}$ Department of Pharmacology, Clinical and Therapeutical Pharmacy UFR Pharmaceutical and Biologic \\ Sciences, Felix Houphouët Boigny University, P.O. Box 1679, Abidjan, 22, Côte d'Ivoire.
}

\begin{abstract}
Crinum species known today are generally used in traditional medicine to treat a variety of diseases such as tumors, fever, malaria, febrile convulsions. The present study was aimed to evaluate the anticonvulsant properties of the aqueous extract of Crinum scillifolium bulbs in mice. The anticonvulsant activity of the aqueous extract of Crinum scillifolium bulbs $(50,100,200$ and $400 \mathrm{mg} / \mathrm{kg})$ was investigated isoniazid-induced seizures in mice. The convulsions produced by isoniazid are due to inhibition of GABA mediated pathway. The aqueous extract of Crinum scillifolium bulbs strongly protected mice against seizures induced by isoniazid (100 $\%$ of protection) at dose of $200 \mathrm{mg} / \mathrm{kg}$. Further, in unprotected animals, the extract significantly increased seizure latency $(p<0.05)$ compared with the control group when mice was treated at dose of $100 \mathrm{mg} / \mathrm{kg}$. Higher mortality was observed in animals that received distilled water. On the other hand, the aqueous extract has considerably reduced the occurrence of death in unprotected animals. The results of this study showed that, the aqueous extract of Crinum scillifolium bulbs possesses anticonvulsant activity against seizures induced by isoniazid in mice. This study strengthened the traditional belief and provided scientific background to the uses of the plant in the treatment of epilepsy.
\end{abstract}

Keywords: Epilepsy, Anticonvulsant, Crinum scillifolium; isoniazid; mice, Côte d'Ivoire

\section{Introduction}

Epilepsy is a chronic brain disease that can affect the entire population of the world. The prevalence of epilepsy in developed countries is estimated to 5\%o and in Africa 10\%o [1].

However $30 \%$ of all patients with epilepsy are estimated to have drug-resistant epilepsy despite a good comprehension of the physiopathological mechanisms and the enrichment of the antiepileptic therapeutic arsenal [2]. It suits to indicate that the adverse effects associated with antiepileptic drugs and recurrent seizures limit their use [3]. Therefore, the search for new therapeutic agents continues, and medicinal plants have emerged as a crucial source for the development of drugs to treat neurological disorders and play an important role for patients who respond poorly to conventional treatments [4.5]. Crinum scillifolium belongs to the family Amaryllidaceae. In Côte d'Ivoire Crinum scillifolium is found in the southwest and in the center precisely in the clearings of the dense forest. However, there is no pharmacological data on this plant, but the literature indicates that Crinum species due to their traditional uses have also been evaluated biologically [6]. Indeed, most of the species evaluated other than scillifolium showed in vitro, important activities such as, anti-cancer, immunological, antioxidant, analgesic, anti-inflammatory and anticonvulsant. This preliminary study was carried out to evaluate the anticonvulsant activity of aqueous extract of Crinum scillifolium bulbs in mice.

\subsection{Plant material}

\section{Materials And Methods}

Bulbs of Crinum Scillifolium were collected from Sikensi, at $80 \mathrm{~km}$ to Abidjan. The plant was identified and authenticated by National Center of Floristics, Department of Botany, University Felix Houphouët Boigny.

\subsection{Preparation of plant extract}

After collection, the Bulbs of Crinum scillifolium were washed with distilled water. They were dried under the shade at $23^{\circ} \mathrm{C}$ and the dried bulbs were ground into fine powder. The powdered material was extracted with distilled water (50 g of powder per $500 \mathrm{ml}$ distilled water) by cold maceration for $48 \mathrm{~h}$ with stirring. The extract obtained constitutes the aqueous extract. The macerate was filtered through Whatman filter paper and 
evaporated to dryness in an oven at a temperature of $45^{\circ} \mathrm{C}$. The extract was stored in refrigerator $\left(4^{\circ} \mathrm{C}\right)$ until ready use. From this various concentration were reconstituted in a known volume of distilled water before administration.

\subsection{Material animal}

Swiss albinos mice $(22-25 \mathrm{~g})$ of either sex were used in this study which were bred in the Laboratory Animal (UFR Pharmaceutical and Biological Sciences; University Félix Houphouët Boigny). The animals were maintained in standard laboratory conditions $\left(25^{\circ} \mathrm{C}\right)$ and light/dark cycles, i.e. $12 / 12 \mathrm{~h}$ and fed with standard food and water. In all the experimental studies, each group consisted of six animals. Each animal was used only once. The investigation conforms to the recommendation of OECD in 2008 [7].

\subsection{Drugs}

Isoniazid 100mg® tablet (laboratory LUTIN, India) was used to trigger convulsions and Clonazepam 100mg® tablet (Laboratory La Roche SA, Switzerland) to protect mice from seizures.

\subsection{Isoniazid-induced seizures}

Six groups each of six mice were administered graded doses of aqueous extract of Crinum scillifolium (50, 100, 200 and $400 \mathrm{mg} / \mathrm{kg}$; p.o.), clonazepam (positive control; 3mg/kg) or distilled water (negative control; $10 \mathrm{ml} / \mathrm{kg}$ p.o). One hour later, all animals were administered orally with isoniazid $(250 \mathrm{mg} / \mathrm{kg}$ ) and placed in isolated cages [8]. Animals that did not convulse within the 3 hours of observation were qualified as protected. In unprotected animals, the latency to first convulsion, duration of first convulsion, latency of death time, percentage mortality was recorded.

\subsection{Statistical analysis}

The data were analyzed using one-way analysis of variance (ANOVA) followed by Dennett's test using the Graph Pad Prism 4.0 software package. The level of significance was determined in comparison with the control group. Statistical significance was accepted for $\mathrm{p}<0.05$.

\section{Results}

As in the INH test, the extract protected animals from INH- induced seizures in dose-dependent manner (Table I). Similar to clonazepam, the extract completely inhibited the onset of INH-induced seizures at the $200 \mathrm{mg} / \mathrm{kg}$ dose.

Moderate protection of $50 \%$ is observed when animals were treated with $50 \mathrm{mg} / \mathrm{kg}$ and $83 \%$ with 100 and 400 $\mathrm{mg} / \mathrm{kg}$ doses (Fig 1). In unprotected animals, the extract at the $100 \mathrm{mg} / \mathrm{kg}$ dose demonstrated a significant increase in seizure latency $(\mathrm{p}<0.05)$ compared with the control group (Fig 2).

Higher mortality was evident for animals that received distilled water and aqueous extract significantly reduced or prevented the occurrence of death in unprotected animals (Table I).

No dose significantly influenced the time to death in animals compared to mice treated with distilled water (Fig 3).

When mice were treated with $50 \mathrm{mg} / \mathrm{kg}$ of Crinum scillifolium extract, a significant increase in the duration of the first crisis was observed ( $\mathrm{p}<0.05$ ) compared to batches treated with distilled water (Fig 4).

No dose significantly influenced the time to death in animals compared to mice treated with distilled water (Fig 3).

When mice were treated with $50 \mathrm{mg} / \mathrm{kg}$ of Crinum scillifolium extract, a significant increase in the duration of the first crisis was observed $(\mathrm{p}<0.05)$ compared to batches treated with distilled water (Fig 4$)$.

Table I: Effect of bulbs extract of Crinum scillifolium in INH-induced seizures in mice

\begin{tabular}{lcc}
\hline Treatment group $(\mathrm{mg} / \mathrm{kg})$ & Convulsion \% & Mortality \% \\
\hline Distilled water & 100 & 100 \\
Clonazepam (3) & 0 & 0 \\
EA 50 & 50 & 17 \\
EA 100 & 83 & 0 \\
EA 200 & 0 & 0 \\
EA 400 & 83 & 17
\end{tabular}

The animals (6 per group) were treated with the aqueous extract, distilled water or clonazepam 1 hour before induction of convulsions with orally administration of $250 \mathrm{mg} / \mathrm{kg}$ dose of isoniazid. 


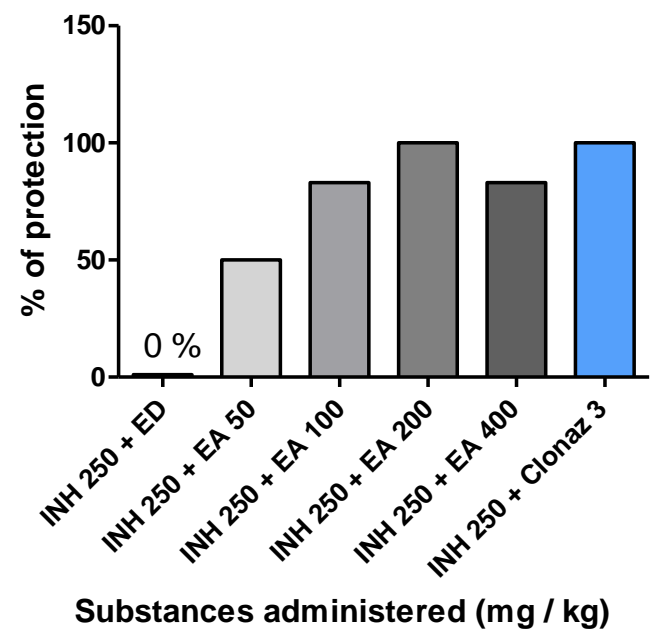

Figure 1: Protective effect of aqueous extract (EA) of Crinum scillifolium bulbs against convulsions induced by isoniazid.

INH $250+$ ED = Isoniazid $250 \mathrm{mg} / \mathrm{kg}+$ Distilled water;

INH $250+$ EA $50=$ Isoniazid $250 \mathrm{mg} / \mathrm{kg}+$ Aqueous extract $50 \mathrm{mg} / \mathrm{kg}$;

INH $250+$ EA $100=$ Isoniazid $250 \mathrm{mg} / \mathrm{kg}+$ Aqueous extract $100 \mathrm{mg} / \mathrm{kg}$;

INH $250+$ EA $200=$ Isoniazid $250 \mathrm{mg} / \mathrm{kg}+$ Aqueous extract $200 \mathrm{mg} / \mathrm{kg}$;

INH $250+$ EA $400=$ Isoniazid $250 \mathrm{mg} / \mathrm{kg}+$ Aqueous extract $400 \mathrm{mg} / \mathrm{kg}$.

INH $250+$ Clonaz $3=$ Isoniazid $250 \mathrm{mg} / \mathrm{kg}+$ Clonazepam $3 \mathrm{mg} / \mathrm{kg}$

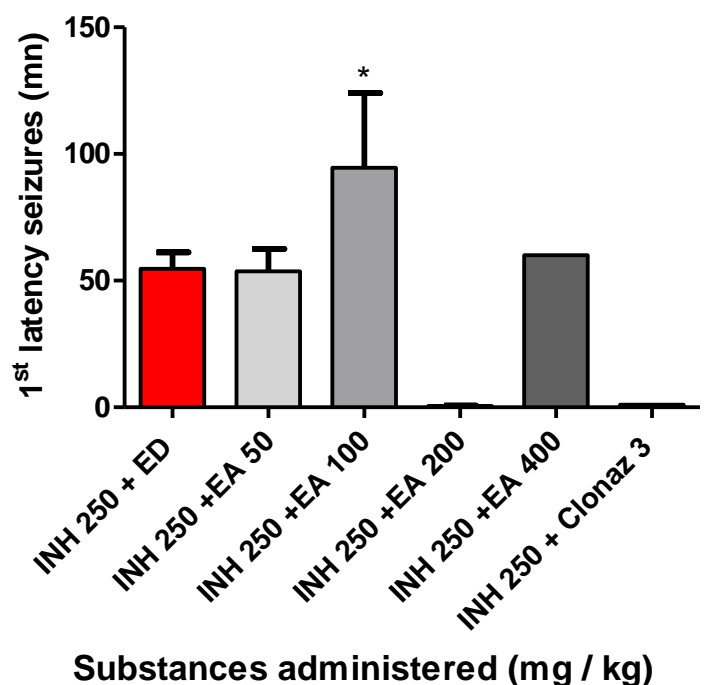

Figure 2: Effect of the aqueous extract of Crinum scillifolium bulbs on latency seizures induced in mice by INH.

The data were expressed as mean \pm S.E.M at risk $\alpha=5 \%$. EA at $100 \mathrm{mg} / \mathrm{kg}$ dose significantly increased seizures latency $(\mathrm{p}<0,05)$ compared to mice treated with distilled water. $n=6$ per dose, ${ }^{*} p<0.05$ The data analyzed by one-way analysis of variance (ANOVA) followed by Dennett's test.

INH $250+$ ED = Isoniazid $250 \mathrm{mg} / \mathrm{kg}+$ Distilled water;

INH $250+$ EA 50 = Isoniazid $250 \mathrm{mg} / \mathrm{kg}+$ Aqueous extract $50 \mathrm{mg} / \mathrm{kg}$;

INH $250+$ EA $100=$ Isoniazid $250 \mathrm{mg} / \mathrm{kg}+$ Aqueous extract $100 \mathrm{mg} / \mathrm{kg}$;

$\mathrm{INH} 250+\mathrm{EA} 200$ = Isoniazid $250 \mathrm{mg} / \mathrm{kg}+$ Aqueous extract $200 \mathrm{mg} / \mathrm{kg}$;

$\mathrm{INH} 250+\mathrm{EA} 400=$ Isoniazid $250 \mathrm{mg} / \mathrm{kg}+$ Aqueous extract $400 \mathrm{mg} / \mathrm{kg}$.

INH $250+$ Clonaz $3=$ Isoniazid $250 \mathrm{mg} / \mathrm{kg}+$ Clonazepam $3 \mathrm{mg} / \mathrm{kg}$ 


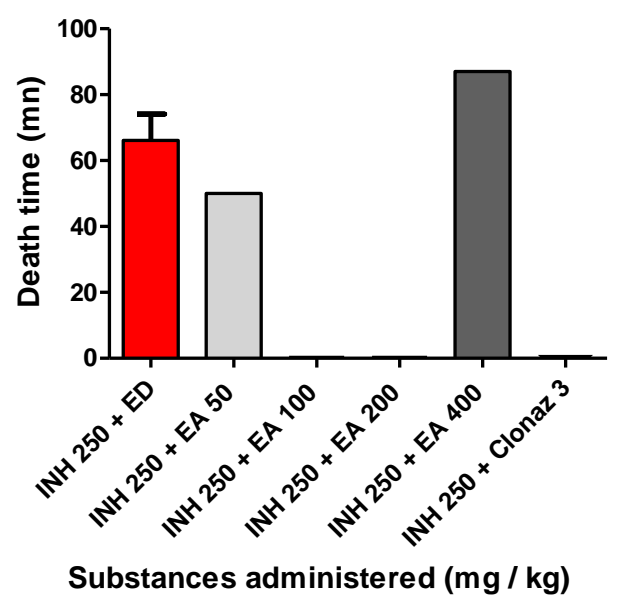

Figure 3: Effect of the aqueous extract of Crinum scillifolium bulbs on death time induced in mice by INH.

The data were expressed as mean \pm S.E.M at risk $\alpha=5 \%$.n $=6$ per dose, ${ }^{*} \mathrm{p}<0.05$. The data analyzed by oneway analysis of variance (ANOVA) followed by Dennett's test.

$\mathrm{INH} 250+\mathrm{ED}=$ Isoniazid $250 \mathrm{mg} / \mathrm{kg}+$ Distilled water;

INH $250+$ EA $50=$ Isoniazid $250 \mathrm{mg} / \mathrm{kg}+$ Aqueous extract $50 \mathrm{mg} / \mathrm{kg}$;

INH $250+$ EA $100=$ Isoniazid $250 \mathrm{mg} / \mathrm{kg}+$ Aqueous extract $100 \mathrm{mg} / \mathrm{kg}$;

INH $250+$ EA $200=$ Isoniazid $250 \mathrm{mg} / \mathrm{kg}+$ Aqueous extract $200 \mathrm{mg} / \mathrm{kg}$;

$\mathrm{INH} 250+$ EA $400=$ Isoniazid $250 \mathrm{mg} / \mathrm{kg}+$ Aqueous extract $400 \mathrm{mg} / \mathrm{kg}$.

INH $250+$ Clonaz $3=$ Isoniazid $250 \mathrm{mg} / \mathrm{kg}+$ Clonazepam $3 \mathrm{mg} / \mathrm{kg}$

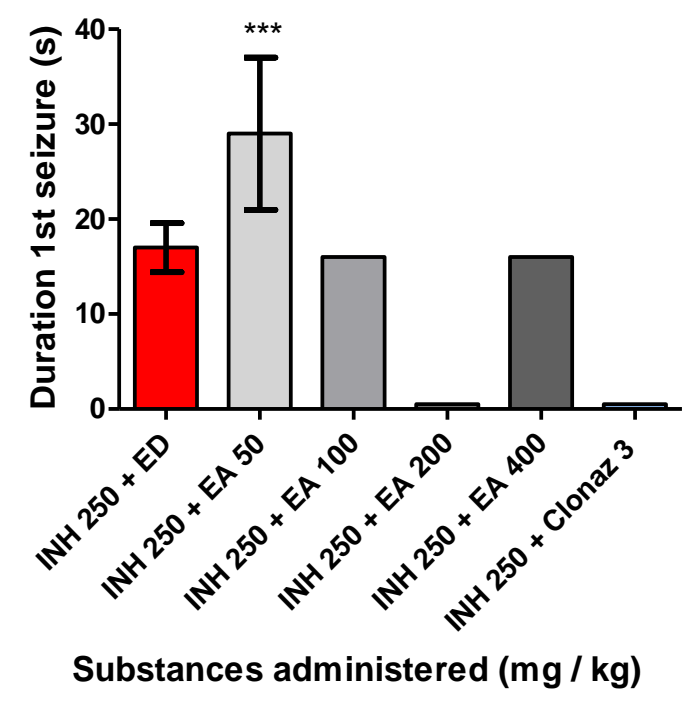

Figure 4: Effect of the aqueous extract of Crinum scillifolium bulbs on duration first seizure induced in mice by INH.

The data were expressed as mean \pm S.E.M at risk $\alpha=5 \%$.n $=6$ per dose, $* * * p<0.02$. The data analyzed by oneway analysis of variance (ANOVA) followed by Dennett's test.

INH $250+\mathrm{ED}=$ Isoniazid $250 \mathrm{mg} / \mathrm{kg}+$ Distilled water;

INH $250+$ EA $50=$ Isoniazid $250 \mathrm{mg} / \mathrm{kg}+$ Aqueous extract $50 \mathrm{mg} / \mathrm{kg}$;

INH $250+$ EA $100=$ Isoniazid $250 \mathrm{mg} / \mathrm{kg}+$ Aqueous extract $100 \mathrm{mg} / \mathrm{kg}$;

INH $250+$ EA $200=$ Isoniazid $250 \mathrm{mg} / \mathrm{kg}+$ Aqueous extract $200 \mathrm{mg} / \mathrm{kg}$;

INH $250+$ EA $400=$ Isoniazid $250 \mathrm{mg} / \mathrm{kg}+$ Aqueous extract $400 \mathrm{mg} / \mathrm{kg}$.

$\mathrm{INH} 250+$ Clonaz $3=$ Isoniazid $250 \mathrm{mg} / \mathrm{kg}+$ Clonazepam $3 \mathrm{mg} / \mathrm{kg}$ 


\section{Discussion}

In the present study, anticonvulsant activity of aqueous extract of Crinum scillifolium bulbs was studied. Isoniazid induced seizures model was used. The convulsions produced by isoniazid is primarily due to inhibition of GABA mediated pathway [9. 10].

It is well documented that INH induced convulsions are produced due to alteration of GABA level in the brain, it reduces the GABA content in the brain by inhibiting glutamic acid decarboxylase (GAD) activity (enzyme responsible for the synthesis of GABA), by combining with pyridoxal phosphate (a coenzyme for its reactions) to form hydrazones and, thus, inhibits the GAD activity [11].

In this study, orally administration of INH induce severe clonic-tonic convulsion in mice which was reversed by clonazepam and the aqueous extract of Crinum scillifolium bulbs at the $200 \mathrm{mg} / \mathrm{kg}$ dose.

On the basis of these evidences, it was presumed that the anticonvulsant effect of the aqueous extract might possibly be producing an antiepileptic action by increasing the level of GABA, an inhibitory transmitter in the central nervous systems. The extract enhanced GABA synthesis either by stimulation of L-glutamate or inhibits GABA catabolism by GABA transaminase, leading to an increase in GABA available in the synaptic cleft. These results are consistent with the results of Azikiwe et al. (2012) which recently showed anticonvulsant activity of fractional extract of bulbs Crinum jagus, a closely related species belonging to the family Amaryllidaceae in mice [12].

\section{Conclusion}

The results of this study showed that the aqueous extract of Crinum scillifolium possess anticonvulsant activity against isoniazid seizures in mice. The present study provides scientific evidence for the use of Crinum scillifolium bulbs in the treatment of epileptic disorders. More studies are necessary to clarify the antiepileptic components and the mechanisms underlying the plant activities.

\section{Ethical approval}

The experimental procedures and protocols used in this study were approved by the Ethical Committee of Health Sciences, University Félix Houphouet-Boigny. These guidelines were in accordance with the European Council Legislation 87/607/EEC for the protection of experimental animals. All efforts were made to minimize animal suffering and reduce the number of animals used.

\section{References}

[1] Doumbia-Ouattara M., Kouame-Assouan A. E., Aka-Diarra E., Kouame L. K., Diakite I., \& Sonan-Douayoua T., 2014 - Epilepsie en milieu scolaire en Côte d'Ivoire données d'une enquête réalisée dans la commune de Yopougon à Abidjan. African Journal of Neurological Sciences, 32(2): 30-35.

[2] Fray S., Ali N. B., Kchaou M., Chebbi S., \& Belal, S., 2015 - Les critères prédictifs d'une épilepsie pharmacorésistante chez l'enfant. Revue Neurologique, 171(10) : 730-735.

[3] Fennell, C. W., \& Van Staden, J. (2001).Crinum species in traditional and modern medicine. Journal of Ethnopharmacology, 78(1), $15-26$

[4] Maertens, P., Dyken, P., Graf, W., Pippenger, C., Chronister, R., \& Shah, A. 1995. Free radicals, anticonvulsants, and the neuronal ceroid-lipofuscinoses. American Journal of Medical Genetics Part A, 57(2), 225-228.

[5] Herrera-Ruiz, M., Jiménez-Ferrer, J.E., De Lima, T.C.M., Avilés-Montes, D., Pérez-García, D., González-Cortazar, M., Tortoriello, J., 2006.Anxiolytic and antidepressant-like activity of a standardized extract from Galphimiaglauca. Phytomedicine 13, 23-28.

[6] Marcus R. Coulston AM. (1985). Water soluble vitamins. In Gilman, A.G., Goodman, L.S., Rall, T.W., and Murad, F. (eds.): “The Pharmacological Basis of Therapeutics." New York: Macmillan Publishing Co., VII ${ }^{\text {th }}$ Edition 1551-1572.

[7] Carlini, E.A., 2003. Plants and the central nervous system. Pharmacology Biochemistry \& Behavior. 75, $501-512$.

[8] OCDE (2008). Repeatead Dose Oral Toxicity Test Method. OCDE Guidelines for testing of chemicals. Organization for Economic Cooperation and Development, Paris, 327.

[9] Raza M., Shaheen F., Choudhary M.I., Suria A., Atta-ur- Rahman, Sombati S., De Lorenzo R.J., 2000 - Anticonvulsant activities of the FS-1 subfraction isolated from roots of Delphinium denudatum. Phytotherapy Research, 15: 426-430.

[10] Silambujanaki, P., Chitra, V., Kumari, S., Sankari, M., Raju, D., \&Bala, T. C. C. H. 2010. Anticonvulsant activity of methanolic extract of Butea monosperma leaves. Research Journal of Pharmaceutical Biological and Chemical Sciences, 1(2), $431-435$.

[11] Schousboe, A., Waagepetersen, H.S., 2007. GABA: homeostatic and pharmacological aspects. Progress in Brain Research 160, 919

[12] Azikiwe C. C. A., Siminialayi I. M., Brambaifa N., Amazu L. U., Enye J. C., \&Ezeani, M. C. 2012 - Anticonvulsant activity of the fractionated extract of Crinum jagus bulbs in experimental animals. Asian Pacific Journal of Tropical Disease, 2: S446-S452. 